\title{
21ST CENTURY TOURISM: THREATS AND OPPORTUNITIES
}

TURISMO DO SÉCULO XXI: AMEAÇAS E OPORTUNIDADES

EL TURISMO DEL SIGLO XXI: AMENAZAS Y OPORTUNIDADES

Mercedes Aznar (maznar@florida-uni.es)*

\begin{abstract}
The good results of tourism in 2016 have raised optimism in the sector however, there is a series of threats that may have a negative significant impact on tourism if they are not paid the required attention. Also, avoiding seasonality and the risk of endangering small rural communities must be considered, as sustainability should be the main priority for all the stakeholders involved, especially this year when the whole world is celebrating the International Year of Sustainable Tourism for Development. Therefore, the objective of this paper is to make an analysis of those threats that can seriously damage the tourist sector but also, of the opportunities that may derive from the dramatic changes our society is going through. This study has been based on four particular areas: health tourism and accessibility; culture, gastronomy and wine; education and technology; and mountain tourism. There are many opportunities the sector can benefit from but only if the parties involved are willing to innovate and become creative.
\end{abstract}

Keywords: tourism, XXI century, threats, sustainability, innovation

\section{RESUMO}

Os bons resultados do turismo em 2016 aumentaram o otimismo no setor. No entanto, há uma série de ameaças que podem ter um significativo impacto negativo no turismo, se não receberem a atenção necessária. Além disso, evitar a sazonalidade e o risco de pôr em perigo as pequenas comunidades rurais também devem ser considerados, uma vez que a sustentabilidade deve ser a principal prioridade 
para todas as partes interessadas, especialmente neste ano, quando o mundo inteiro comemora o Ano Internacional do Turismo Sustentável para o Desenvolvimento. Assim, o objetivo deste trabalho é fazer uma análise das ameaças que podem danificar seriamente o setor turístico, mas também sobre as oportunidades que podem resultar das mudanças dramáticas que a nossa sociedade está a passar. Este estudo baseou-se em quatro áreas específicas: turismo de saúde e acessibilidade; cultura, gastronomia e vinho; educação e tecnologia; e turismo de montanha. Há muitas oportunidades de que o setor pode beneficiar, mas apenas se as partes envolvidas estiverem dispostas a inovar e a tornarem-se criativas.

Palavras-chave: turismo, século XXI, ameaças, sustentabilidade, inovação

\section{RESUMEN}

Los buenos resultados turísticos en 2016 han elevado el optimismo en el sector; sin embargo, hay una serie de amenazas que pueden tener un significativo impacto negativo en el turismo si no se les presta la debida atención. Por otro lado, evitar la estacionalidad y el riesgo de llegar a poner en peligro las pequeñas comunidades rurales deben asimismo ser tenidos en cuenta puesto que la sostenibilidad debería ser la principal prioridad para todas las partes involucradas, especialmente este año en el que a nivel mundial se está celebrando el International Year of Sustainable Tourism for Development. Así pues, el objetivo de este artículo es llevar a cabo un análisis de aquellas amenazas que pueden dañar seriamente al sector turístico pero también de las oportunidades que se pueden derivar de los considerables cambios por los que está pasando nuestra sociedad actual. Este estudio se ha basado en cuatro áreas en particular: el turismo de salud y la accesibilidad; la cultura, la gastronomía y el vino; la educación y la tecnología; y el turismo de montaña. Existen muchas posibilidades de que el sector pueda beneficiarse. Bastaría con que las partes implicadas estuvieran dispuestas a innovar y optaran por la creatividad.

Palabras clave: furismo, siglo XXI, amenazas, sostenibilidad, innovación 


\section{Egitania}

$s$ c i e $\Omega$ c i a

* Ph.D. Professor in the Engineering and Business Studies Programmes at Florida Universitaria (Catarroja, Valencia, Spain) since 1996.

Submitted: 19th June 2017

Accepted: 4th December 2017 


\section{INTRODUCTION}

In response to the Open Letter on Travel and Tourism presented to the Prime Minister of Malta, Dr. Joseph Muscat, by the World Tourism Organization (UNWTO) and the World Travel and Tourism Council (WTTC) at the end of May 2017, he concluded that tourism "( ) is actually one of those areas through which we believe that wealth percolates to all sections of society in a direct manner". Surely, tourism nowadays is much more than culture, cruises, events, and the like. And although visitors figures are on the rise, we cannot remain in our comfort zones, since trends can adopt flickering ways. This is why during the Malta meeting two interesting events were implemented having in mind the need to innovate and compete adequately: on the one hand, a masterclass on how to attract Chinese tourism to the Mediterranean countries (a big and powerful market that cannot be ignored); and on the other, an event on how to enhance Europe's tourism competitiveness through new products. In other words, innovation and creativity are a must to succeed.

As mentioned above, there was a significant increase in the number of worldwide visitors during 2016: over 1.2 billion tourists, i.e. a rise of 3.9\% compared to the previous year (UNWTO, 2016d). This means 2016 represents the 7 th consecutive year of sustained growth after the global economic and financial crisis that stroke worldwide from 2009. Nevertheless, figures fluctuate depending on destinations and thus, Europe presented mixed results although the number of visitors increased by $2 \%$. There has been a solid growth in countries such as Spain or Portugal.

However, France and Belgium experienced a considerable decline which is more than likely due to the recent terrorist attacks by the socalled ISIS (Islamic State of Iran and Syria). Bearing this in mind, we may say that certain countries are experiencing a kind of "borrowed tourism", since visitors are fleeing conflict areas and so, spreading towards other destinations. Undoubtedly, this is a great opportunity for those countries to create a solid basis for their tourism strategy and indeed, customer loyalty is of paramount importance here. Consequently, innovation becomes a key factor. And although terrorist attacks are a tremendously serious impact factor, other challenges cannot be ignored that can seriously affect tourist destinations. 


\section{CHALLENGES AHEAD}

No country can claim to be free from risks at present. There are many dangers that can affect not only tourism but the whole destination's economy and welfare state. Some relevant challenges are presented below in order to illustrate this point:

Natural disasters. The whole world remained speechless in the aftermath of the terrible earthquakes that devastated central Italy last summer, where almost 300 people died. Besides the terrible impact of the high rate of deaths, whole villages and consequently, their cultural heritage were practically destroyed (if not entirely). Tourist destinations such as Amatrice, Accumoli or Arquata del Tronto have been demolished. A long time will be needed before those areas come back to life, if they do. In sum, this natural disaster has meant the personal and economic ruin of all the surviving inhabitants in the area. In addition, a good number of both customary and prospective tourists may now consider Italy as a potentially dangerous destination if they are willing to enjoy a relaxing holiday.

Other destinations have suffered greatly from natural causes, as for example, the destruction of tourist places such as Aruba, St. Lucia or even the States because of hurricane Matthew last September; or the havoc wreaked by Cyclone Vardah in Thailand and India last December, just to mention a few.

Health-related pandemics. The Ebola outbreak that initiated in 2013 and was not officially declared as terminated until 2016 expanded the fear of travelling, since the easy and fast spread of the disease placed the global population in serious risk of contagion. Likewise, the Zika virus epidemic put the celebration of the last Olympic Games in Brazil at stake when the World Health Organization proclaimed the virus as an international emergency case for public health worldwide early in February 2016, just five months before the start of the Olympics (even some of the participants to the Games refused to travel to Brazil).

Political instability. The rise of nationalism across Europe will surely affect travelling to certain destinations because of the conflict arising from it. Without a doubt, the most significant consequence of this is the "Brexit" case that stroke the whole of Europe in June 2016; and we have not 
seen yet the whole scenario, as negotiations are still ongoing, but what can be already observed is variations in the value of the British currency and especially, a difference in how people from certain countries are regarded even when visiting on their holiday.

Crisis communication is key to diminish impact on tourism. Therefore, all tourism stakeholders should cooperate in order to provide immediate, effective and reliable support when the problem occurs. As the UNWTO Secretary-General, Taleb Rifai, said "tourism is one of the most resilient and fastest-growing economic sectors but it is also very sensitive to risks, both actual and perceived" (UNWTO, 2016b).

Perception is as dangerous as reality and hence, building confidence among travellers should be a must. In order to address this issue, the first meeting of the UNWTO High Level Task Force on Tourism and Security was held early last May with the objective to integrate national security with tourism security, crisis communication and travel counselling; and which counted on the participation of UNODC (United Nations Office on Drugs and Crime), IATA (International Air Transport Association), PATA (Pacific Asia Travel Organization), WTTC (World Travel and Tourism Council), BTW (Federal Association of the German Tourism Industry), and ABTA (British Travel Agencies). This Task Force will also work on seamless travel, including visa facilitation (despite the difficult situation worldwide), and especially, on crisis communications.

In spite of the hard times we are facing nowadays, figures speak for themselves, since tourism accounts for $7 \%$ of worldwide exports; it provides 1 in 11 jobs; it represents 10\% of the world's GDP; and it is the third worldwide export category (UNWTO, 2016d). As a result, there is no room for complacency and efforts to improve are more important than ever. Furthermore, all the present initiatives must also focus on sustainability and development, as 2017 has been declared as the International Year of Sustainable Tourism for Development by the UNWTO. 


\section{THE INTERNATIONAL YEAR OF SUSTAINABLE TOURISM FOR DEVELOPMENT (IY2017)}

"There are many reasons for declaring 2017 as the International Year of Sustainable Tourism for Development, such as greater appreciation of different cultures and thus peace among peoples," said His Majesty Felipe VI, King of Spain, at the UNWTO's launch of IY2017 last March in Madrid; and surely, this is one of the most important aims of this initiative, together with a mutual understanding among cultures; and also, to become a powerful tool that should ensure tourism as a pillar in achieving the 17 Sustainable Development Goals (SDGs), UNWTO resolution approved in September 2015 whose target is to end poverty, protect the planet, and ensure prosperity.Moreover, SDGs encompass the 2030 Agenda for Sustainable Development, another ambitious initiative developed by the United Nations and which is to be implemented worldwide. Concerning tourism, the objective of the IY2017 (UNWTO, 2017c) is to promote the role of tourism in 5 key areas: 1. Inclusive and sustainable economic growth; 2. Social inclusiveness, employment \& poverty reduction; 3. Resource efficiency, environmental protection and climate change; 4. Cultural values, diversity and heritage; and 5. Mutual understanding, peace and security.

This is a vast endeavour that will be also implemented in collaboration with the UNWTO International Network of Sustainable Tourism Observatories. There are already interesting initiatives in line with sustainability as China, which is a leading tourism destination - actually, it ranked 4th after France, USA and Spain in 2015 (UNWTO, 2016d) and has established a strategic plan aiming to reduce poverty rates by 2020. Or Malaysia, the 2nd most visited destination in South-East Asia, that has created an Economic Transformation Programme (PEMANDU, 2010) in order to boost rural and youth tourism, ecotourism, families, business, entertainment, etc. Or Portugal, which presented last February their Portugal 4.0 project (Portugal Ventures, 2016); this has the objective to foster innovation and entrepreneurship in the tourism sector and to work on areas such as the rehabilitation of historical buildings inland and the promotion of routes through natural areas. Certainly, all these actions should develop according to the UNWTO Global Code of Ethics for Tourism (UNWTO, 2001); up to June 2017, 514 companies and 
associations from 68 countries have already committed to it. The Code is voluntary so far however, work is being developed towards changing it into an international Convention that would convert it into a binding instrument worldwide. There is a strong likelihood this resolution may be adopted in the UNWTO General Assembly that will be held in China next September 2017.

Once the background has been set concerning both the present situation and actions being implemented in the tourist sector worldwide, an analysis on threats and opportunities as well as trends will be presented with regard to four main tourism areas: 1 . Health, welfare and accessibility; 2. Culture, food and wine; 3. Education and technology; and 4. Experiences in mountain territories.

\section{HEALTH, WELFARE AND ACCESSIBILITY}

Health is always a relevant issue but nowadays public opinion is placing special relevance to it. As a result, medical tourism has become a growing segment, which has been evidently acknowledged by the UNWTO and also, the European Travel Commission through a common research called Exploring Health Tourism that establishes common grounds for creating a health-related taxonomy (UNWTO, 2016a). It is an important attempt to provide a coherent construct of health-related tourism and also, to deepen in the motivations behind travellers looking for health-related services.

Medical tourism is a major pillar of certain global economies, with a revenue of about $€ 50$ billion in 2016 (MedHalt, 2016). A medical tourist would spend between six and ten times more than a conventional one, which is not surprising if we look at the wide range of possible treatments they would search for, ranging from odontology or cancer treatment to fertility ones. A Spanish example of best practice on fertility treatments will clearly illustrate this point: the biggest centre in Europe in assisted reproduction with patients from nearly 100 different nationalities (this represents $25 \%$ of their total patient rates), and with an annual turnover of about $€ 170$ million. As a private clinic, the cost of these treatments can range from about $€ 1,000$ to $€ 8,000$, if the insemination or fertilisation therapies are successful already from the initial treatment. Consequent- 
ly, the target market revolves around high income couples that will also need accommodation, eating out, shopping, and all sorts of tourism services during their stay. The impact on the local economy is doubtless significant.

Another sector in tourism related to health services is wellness. However, sometimes the difference between medical and wellness tourism does not seem to be clear-cut, and therefore a definition will be provided. According to the Global Spa Summit (2011), the medical tourist is an individual who is normally ill or rather seeks for some kind of treatment or surgery. On the other hand, the wellness tourist generally looks for offers that integrate mental and physical health and treatments to prevent illness with the objective to improve both their health and quality of life. If we have a look at relevant figures and data, wellness is a sector of major importance in tourism, since total revenues for 2015 were \$3.72 trillion, in other words, $15.6 \%$ of total tourism gains (Global Wellness Institute, 2016). In addition, tourist expenditure is particularly relevant, as wellness tourists spend $61 \%$ more than the average travellers. Moreover, wellness tourism even saw a significant increase of 10.6\% during 2013-2015, while the global economy was in recession. Finally, it provides 17.9 million jobs worldwide. So, it is no doubt one of the world's fastest growing and more resilient markets. And wellness will remain on the rise as demanded by today's society where there is an emerging global middle-class despite the economic recession, and also, the world population is aging rapidly. We are dealing here with the so-called LOHAS (Lifestyles of Health and Sustainability) segment characterised by wealthy and educated consumers in search of experiences based on authenticity and nature. For this reason, a wide range of offers is available for them such as, cruises with wellness experiences; or wellness programmes at airports, where the traveller can relax either in quiet rooms or in indoor green spaces or walking tracks, or simply enjoy organic and vegetarian cuisine.

Some of the new trends at present are related to stress consequences, a major cause of disease nowadays. Only in the United States, $77 \%$ of people suffered physically from stress in 2014 and $73 \%$ psychologically (The American Institute of Stress, 2014); and these figures are not decreasing. For this reason, the traveller has on offer stop-smoking retreats for example, with specialist therapies; or pack holidays where mind and 
emotion healing is key and specialists provide aid to reconnect mind, body and soul. Other trends relate to serious health issues such as cancer and it is here where there is a clear overlap of medical and wellness tourism in many cases.

Post-cancer recovery retreats or physical therapy holidays are good examples where the tourist enjoys spa therapies and alternative natural medicine treatments integrated with medical specialists consultations in the former; and physiotherapy integrated with other treatments as aquatic therapy in the latter. As nutrition is an important factor in health, another option is the so-called eat-well detox holidays so that visitors can enjoy healthy diets but also, work towards losing weight in a healthy and delicious way.

In order to widen the prospective customers spectrum, interesting options are available. Wellness to heal workplace problems is not exactly new, as this has been going on for a long time where the tourist can enjoy relaxation through spa therapies; but what is new here is the fact that companies are offering this pack as a way to encourage team-building as well. Another interesting option is wellness for the whole family so that we can find even mini-spa treatments for children; the objective here is to offer relaxation for parents, as they can enjoy their wellness treatments while their children are enjoying theirs but also, to make sure that children become disconnected from their technological gadgets (iPad's, smartphones, and the like) during their stay. Therefore, new sports and activities are programmed for children apart from the spa ones. One more relevant offer concerns the concept of the modern man, i.e. men who are interested in their health and well-being, which includes not only spa therapies but also cosmetic ones, all integrated in the wellness pack. And finally, holiday packs are on offer for those individuals who wish to travel with their friends but also, for the solo traveller who is given the opportunity to join a group of people with similar likes and wishes; they are fitness holidays where people train in groups, thus, giving them the chance to learn from one another but also, to make lifelong friends. These are only a few examples to illustrate how the sector is trying to cover the present market demand.

As regards accessibility, although UNWTO and the European Union have been working on this issue for a long time, there is still much room for improvement. This is why the IY2017 focuses once again on it be- 
cause we cannot ignore that there are one billion people around the world with special needs, i.e. 15\% of the world's population (The World Bank, 2017). But this figure rises when we also include here seniors and families travelling with small children. As the former UN Secretary-General Ban Ki-Moon said during the World Tourism Day 2016 officially celebrated in Bangkok under the theme "Tourism for all - promoting universal accessibility", "Everyone has the right to access leisure and tourism services on an equal basis". It is extremely important to erase that concept that still exists of accessibility as a burden in business: if all products and services had the objective to increase accessibility, more value would be added and as a result, this would become a tremendous opportunity for the business sector. And although we cannot ignore the fact that accessibility may be rather complex in areas such as mountain tourism, creativity can establish the difference among destinations.

It is for this reason that the Technical Committee TC228 has been created aiming to work on tourism and related services within the International Organization for Standardization (ISO). This team is responsible for developing a standard to be operational globally, i.e. ISO21902 Tourism and related services - Tourism for all - Requirements and recommendations (ISO, 2017), aiming to establish guidelines for tourism planning and destination management; it is expected to be approved in 2018 and promulgated during 2019.

\section{CULTURE, FOOD AND WINE}

Gastronomy is an essential component of history and nowadays it has become a major motivation to visit a destination; only in the US, over 75\% (Stone et al., 2016) of leisure travellers consider culinary experiences to be a major factor when arranging their holiday trips. Needless to say, this particular tourism area has proven to be relevant both in impelling local and particularly, rural destinations and strengthening sustainability, thus contributing towards the principles of sustainability being at stake through IY2017 as well as committing to the protection of cultural values, heritage and diversity which are so important in heritage tourism. Certainly, there is a clear relationship between food and culture which has become a major catalyst for sustainable tourism, since gastronomy 
tourism reveals the authenticity of every selected destination.

According to the 2016 Food Travel Monitor published by the World Food Travel Association (Stone et al., 2016), trends at present are based on a return to culinary roots in search of authentic experiences. For example, the concept of meal sharing is on the rise: focus is placed on integrating the tourist with local chefs, homeowners and tour leaders, as a way to foster active participation in food sourcing (e.g. local culinary festivals, culinary days, rural culinary fairs, etc.). Establishing this kind of networks is always positive for the communities involved because these become reinforced; and also, individuals such as chefs or homeowners are provided with the power to create new companies and as a result, local development is boosted and the community identity becomes strengthened.

Another trend is culinary storytelling. i.e. specific content is used to design trips that entail authentic experiences and memorable journeys. An example of this could be the days of Celtiberian cuisine that are organised in some parts of Spain, whereby the visitors are offered a cultural visit to archaeological sites focusing on the history of this particular cuisine; then, they are transferred to small rural restaurants where chefs and business owners provide visitors with a description on how meals were cooked in Celtiberian times; and finally, visitors enjoy the culinary heritage experience (farm-to-table cuisine is a major feature here). And of course, they can also enjoy traditional local agricultural products and craft in the small shops of the rural community.

Finally, home-cooking is another trend that relies on going back to communities' roots; a trend that is quite common in the US by which visitors are invited to private households where the owner cooks for them with the local products and using the local traditional recipes.

These are just a few examples of what new trends are aiming at just now and in sum, we can say that the main focus lies on a shift towards tradition understood as authenticity. As a result, there is also a shift in the potential customer, since interest now does not rely on Michellin-star restaurants tours but rather on health and wellness, and on achieving a better understanding of ingredients, their origins and benefits. Thus, we are witnessing a redefinition of the concept of luxury in which the new generation called millennials (those individuals born after 1980 and the first generation to come of age in the new millennium) has a major role 
because one of their characteristics is their search for genuine experiences. Moreover, it is the biggest generation in the history of the United States for example and so, this market must be seriously taken into account businesswise.

Wine tourism is a key component of gastronomy tourism and also, a growing segment. Obviously, it has a close link to culture, history and lifestyle and as is the case with culinary tourism, it also contributes to the development of the tourist sector. This is why it has a global support: on the one hand, UNWTO has created the Wine Tourism Prototype as an evaluation tool on the impact of wineries at a cultural, economic, social and environmental level; its objective is to help emphasise aspects such as culture, history and tradition. On the other hand, the European Network of Wine Cities launched in 2012 the European Wine City competition, an important initiative to empower rural communities; this year the winning capital is Cambados (Spain), a municipality of about 14,000 inhabitants which has a lot to gain if full advantage is taken of this great opportunity.

The trends in this segment revolve around establishing partnerships of wineries with tour operators in order to present wine tourism as a new experience, by making visitors enjoy the wine making experience firsthand and also, making their own blends which will be labelled later on; or by making tours unique though tractor trips, for example, along the vineyards so that visitors become educated about their different features. The creation of wine villages is another attractive focus for potential tourists whereby the whole destination becomes a kind of thematic park and the tourist can become familiar with the history and tradition of wine through stores, restaurants, museums and in some cases, also spas. On the whole, the main point in all these initiatives is to arrange activities (tourist packages) involving eco-tourism concerning wildlife, thus a particular segment is aimed at here i.e. LOHAS, since they have an interest in wine as a natural product and at the same time, as the basic source of income for many winemakers' families; and also, they place an emphasis on sustainability associated with local products and regionality, in other words, culture.

As already mentioned, heritage tourism is doubtless of paramount importance at a regional level because among many different reasons, it is recession-proof and it can help towards avoiding seasonality so conse- 
quently, regional cooperation and the active involvement and participation of all the stakeholders is a must. Therefore, it is no wonder that there are so many initiatives to foster, enhance and enrich cultural tourism.

Concerning support by UNWTO, an interesting action is The Phoenician Tourism Route covering various periods of the Phoenician heritage with routes that will connect 3 continents, 18 countries and more than 80 towns. It was launched last November and as Europe is also part of the itineraries, its great potential has also been recognised by the Council of Europe. Another initiative is The Path of Pearls in Bahrain, listed by UNESCO as World Heritage Site, where the visitor can learn and experience pearl-diving and the harvesting of oysters, and how those beautiful and unique pearls have become the particular source of income of their inhabitants, which has enabled the island to develop a specific economic, cultural and social system. And surely, the most relevant initiative is The Silk Road Tourism, an ongoing project work in collaboration with UNESCO, which was first raised at UNWTO's General Assembly in 1993. It is a vast endeavour that intends to join 3 continents and cover over 12,000 $\mathrm{km}$ and which has 33 Member States participating so far. However, the major objective is to use this route as a vehicle for promoting peace and cultural understanding among nations and although war conflicts and terrorist attacks are a major threat, there is a worldwide manifest interest in this initiative (related to this, China has recently launched The New Silk Route - called OBOR, One Belt, One Road - with the objective to take advantage of the commercial benefits that can derive from this ancient route). This is why TripAdvisor presented last March their second survey on travel trends for the silk road, a report that assesses travel preferences, habits and interests along the route (TripAdvisor, 2017). They concluded that visitors' top interests were first, to visit UNESCO World Heritage Sites; second, to experience the local gastronomy; and finally, to attend local festivals and events.

The European Commission also supports initiatives in this line such as, The European Capital of Culture (this year being a twofold action with Aarhus in Denmark, and Pafos in Cyprus) that was first launched in 1985. These actions can have a significant impact on the regional economy and local community if they are developed and managed in the right way; and what is more important, they can lead to an increase in citizens' pride by sharing their local values and history with visitors, and 
as a result, a major impact on the business community. In addition, it is worthwhile to recall that 2018 will be the first European Year of Cultural Heritage, an initiative that will surely enhance cultural tourism in the continent by making potential visitors become interested and involved in our cultural traditions. So, once again creativity and innovation will be crucial factors to succeed in heritage tourism, especially in small communities enriched by their own heritage but which have to work harder to find their niche. Hopefully, this new action starting in a few months will become a solid support for them.

\section{TECHNOLOGY AND EDUCATION}

21st century tourism should rely highly on technology, as our society is nowadays. Those who ignore this are left behind and this is something that tourist destinations and the tourism sector in general cannot afford. Digitalisation is a must in all sectors of the economy and in tourism there is a need for digital applications that should provide customised services, so much in line with the spread concept of "tourists first". The new millennium, and new century, tourist is constantly connected and informed and also, demands authentic, unique and valuable experiences; and applications and latest technology can add support towards this target. On the other hand, applying this digitalisation will also represent a differentiation among tourist destinations aiming to not only add value but to preserve natural, social and cultural environments as well. And doubtlessly, modern technologies should cater for people with visual, hearing, mobility or cognitive impairments who are left behind in many tourist destinations.

In this line, the UNWTO supports the concept of "smart destinations" and for this reason, last February the first Smart Destinations World Conference was held. Participants concluded that innovation, technology and sustainability are the pillars of smart destinations in dealing with the intelligent promotion of tourist sites, digital accessibility, big data and open platforms, or the sharing of existing applications, among many other relevant issues. As Mr Taleb said during the Conference, "smart tourism is not a trend, but the future of tourism development" (UNWTO, 2017a). 
However, technology must also be used towards a sustainable society and the tourist sector must follow. As Europeans, we must comply with the European Commission's Nearly-Zero Energy Hotels (neZEH) e-toolkit (mww.nezeh.eu), a three-year European-funded project in the framework of the Intelligent Energy Europe Programme, that was launched in 2016 and whose objective is to fight climate change by assessing the energy performance of hotels. This toolkit recommends measures that should improve and increase the use of renewable energy leading to a nearly-zero consumption. So far, the project is in the piloting phase in which 7 European countries have already participated i.e. Croatia, France, Greece, Italy, Romania, Spain and Sweden. Nevertheless, all EU Member States are required to meet the neZEH regulations by 2020. Concerning some of the trends we can observe in the sector, TV booking is indeed an increasing practice that should be looked upon. Technology has evolved tremendously with regard to TV sets and the latest smart devices with Internet connection offer possibilities that seemed to be unthinkable not long ago, since the new customer can easily booked a holiday just sitting comfortably in front of the telly. This is unquestionably a very positive development for the tourist customer, however the fact that this will seriously affect the travel agency sector is also unquestionable. A redefinition of this sector will be indispensable, otherwise travel agencies are bound to disappear. In this sense, there is a new tool that some travel agencies have already started using, i.e. the virtual reality. This technology is ideal for travellers to choose a destination because it allows them to see it in depth in a kind of "try-before-you-fly" service. Once in destination, there are two new technological developments that have recently appeared on the market. On the one hand, we can find the new concept of digital payment now understood as a digital forex wallet which allows the traveller to spend and store money, and also, to convert multiple foreign currencies. And on the other, chatbots will be an invaluable help for travellers for example for communicating directly with people in a foreign language. These are computer programmes, in the form of a virtual email correspondent, that can reply to messages from computer users. Needless to say, this is a revolution in the travel industry and in particular, in the so-called conversational commerce (chatting through Whatsapp or Facebook Messenger, for example). However, there is still a long way to go because the main obstacle here is the 
availability of technology in tourist destinations.

It has been mentioned before that a number of activities will be developed in order to promote and strengthen the 5 key areas of the IY2017. And with regard to education, a focus will be placed on the area "Capacity building and education" (UNWTO, 2017b) by working on three specific lines of action: 1. promoting the creation and implementation of educational policies to support sustainable tourism for development; 2. improving the existing curricula towards the 2030 Agenda and SDGs so that students should learn and reflect on the requirements derived from both; and 3. enhancing knowledge and skills in the case of women and young people, who are suffering the consequences of unemployment rates. In order to implement these, the UNWTO suggests a number of activities that should be carried out by all the stakeholders involved: workshops and training on sustainable tourism focused on capacity-building; exchange programmes both regional and international; tailored present curricula to also include the requirements described by the Global Code of Ethics for Tourism; and vocational training programmes for disadvantaged groups, as mentioned earlier. Hopefully, the education sector will be willing to contribute to these actions and consequently, improve greatly students' training; further analysis at the end of IY2017 should be done so as to find out to what extent higher education institutions have participated in this initiative and their outcomes.

Some institutions have already anticipated and established new programmes, as Les Roches International, a prestigious institution for tourism studies recognised worldwide. A few examples will suffice to illustrate this point. They have signed cooperation agreements with certain emerging economies in order to help develop the local talent (e.g., they have set up a hospitality management institution in Rwanda). Also, they foster the digital advantage by integrating digital skills into their hospitality and management programmes for helping students develop innovation technology and digital skills; and besides, students are trained on how to use technology to create seamless travel experiences. Furthermore, this institution has created a Postgraduate Diploma in Marketing Management for Luxury Tourism aiming to make students aware of the impact of new technologies and trends to become leaders in the market and in innovation if they want to meet the demands of luxury travellers. These are only a few examples that could make universities and colleges re- 
flect on the curricula and training programmes they are offering, analyse the present situation (taking into account the lines of action suggested above), and focus on creativity and innovation so that they can also establish their niche on the market by educating the $21 \mathrm{st}$ century undergraduate and graduate students.

\section{EXPERIENCES IN MOUNTAIN TERRITORIES}

Mountain tourism has a powerful potential for the sustainable development and economic growth of rural communities. However, it can also be very negative for mountain territories because of the impact visitors can cause. Firstly, the highest risk is environmental because the fragility of the ecosystems can get easily damaged by travellers. Then, at a socio-cultural level, rural communities are threatened due to the use - and abuse - of natural resources but most importantly, the adoption of foreign traditions at the expense of local ones can seriously damage them; likewise, the concentration of visitors in small areas contribute negatively to an increase of noise that disturbs considerably the local inhabitants. Finally, economically speaking, not all the revenues generated by this kind of tourism stay in the community, since many externally-owned companies create the required services and hence, enjoy the profits from them; moreover, there is a seasonality factor that still remains a significant burden especially in the case of snow tourism; in addition, there is a high rate of short-term employment and low wages that does not add value to the community and perhaps even in the short term, to the destination itself.

However, well-planned and well-managed tourism can improve infrastructures, provide community services and help diversify local economies. In a report on the state of affairs by the University of Geneva (2014), they concluded on a number of actions to optimise mountain tourism and also, protect the environment: 1. the adoption of a community-based approach which would surely reinforce tourism sustainability; 2. the correct management of visitor flows and above all, the development of strategies aiming to educate visitors and tourist stakeholders on the need for conservation; 3. the development of networks that would involve both public and private stakeholders in order to provide resourc- 
es, models, and experiences; and since mountain chains often constitute borders among countries, 4. the development of cross-border tourism with the objective to strengthen sustainability and environmental protection through inter-regional and international cooperation and coordination.

The potential of tourism to preserve biodiversity is unquestionable but a coordinated effort must be undertaken to ensure that awareness is raised on this issue. However, without the engagement of the tourism community and sustainable alternatives for local communities, this potential is seriously endangered. Mountain tourism can provide tourists with unforgettable experiences but as already mentioned, it can also be sustainable and profitable thus creating great opportunities for the rural areas.

As Erick Solheim (Executive Director of the United Nations Environment Programme - UNEP) rightly said during the UN Biodiversity Conference COP13 held in Mexico last December, "Tourism is one of the biggest job creators on planet Earth. So if we protect biodiversity, we are creating jobs" (UNWTO, 2016c). But if this is to be achieved, there should be a reinforcement of national commitments to The Paris Agreement and The 2030 Sustainable Development Agenda. Consequently, if tourism remains committed to fight climate change, the whole society will benefit from it. And it is with good reason that the Convention on Biological Diversity of the UN chose "Biodiversity and Sustainable Tourism" as the theme for the International Day for Biological Diversity that took place last May.

Interesting initiatives are being implemented towards sustainability in the sector. One of them is the UNWTO World Congresses on Snow and Mountain Tourism organised by the UNWTO and the Government of Andorra and that have been held every two years since 1988, the last one in March 2016. Their objective is to analyse the challenges and opportunities of the snow and mountain destinations and as a result, adopt successful business models based on innovation. The focus of the last edition was placed on innovation to minimise seasonality through the promotion of new activities related to nature, sports, culture, gastronomy, and wellness. In this way, the visitor is not only offered skiing activities and so, an interesting and valuable experience can be achieved when travelling to these destinations at any time during the year. 
Another initiative is InRuTou (inrutou.eu), a European-funded project in the framework of the Lifelong Learning Programme. It is a partnership of a number of different organisations, also including EURAC (Institute for Regional Development and Location Management). The objective is to develop and test an innovative model that would facilitate and enhance rural tourism in mountain regions.

Finally, the Sustainable Mountain Tourism Alliance (STMA) comprises the tourism industry, NGOs, the private sector, and academia. It was founded in January 2015 with the objective to establish a comparable standard of quantitative sustainability assessment in mountain regions worldwide. But as they claim, and this is applicable to all cases, a better coordination and cooperation should be enabled in order to measure and communicate all the efforts in sustainability in mountain regions.

These are only a few examples that should highlight the importance of joining forces in order to reach a common goal, i.e. the protection of our environment, the visitor's satisfaction, and the sustainability of the rural mountain communities.

\section{CONCLUSIONS}

Tourism is a source of economic wealth for countries and a powerful source of economic growth and stability for small rural communities. Despite the rising figures in tourist arrivals worldwide, many threats to tourism must be watched closely and besides, crisis management and communication in these cases should be of paramount importance to diminish impact on the tourist sector. The capacity to succeed in potential negative scenarios would add to the sustainability of tourism and thus, comply with the recommendations suggested by the UNWTO through the 2017 International Year of Sustainable Tourism for Development.

Four specific tourist areas have been tackled in this paper in order to present a description of those threats that must be watched upon but also, the opportunities available if we focus both on the new scenarios that the present society demands and also, on particular segments, as the LOHAS or the millennials, which are considerably powerful for the sector. These potential customers are key in medical and wellness tourism where they search for genuine experiences that would enhance their 
well-being both health-wise and psychologically.

Consequently, quality cuisine is demanded - understood at present as a search for the natural source (the natural ingredients) and traditional recipes; likewise, wine tourism plays a key role here as wine is also seen from the quality perspective and the return to the roots. Altogether, culture encompasses all the above and thus becomes a major attraction for tourist destinations, whereby heritage may result a notable added value to establish preferences in choosing a tourist holiday. However, sustainability is key in the particular case of small communities in order not to destroy them; a wide range of initiatives are being developed towards this aim and especially, particular attention should be placed next year to the first European Year of Cultural Heritage, announced by the European Commission and which will definitely provide all those tourist parties interested in it with relevant projects and new actions to be implemented. An analysis has also been made on mountain tourism, a sector which should be subject to thorough study in order to ensure the preservation of the environment and its fragile eco-systems on the one hand, and on the other, to enhance the life of rural communities in mountain territories as well, but safeguarding their traditions and lifestyle; tourism can have a significant potential to protect biodiversity but this could only occur if all the stakeholders involved work towards a common goal.

Moreover, the high speed at which technology advances is decisive in establishing added value and consequently, a differentiation among destinations; ignoring the importance of digitalisation or smart destinations will inevitably lead to failure, with the implications that may derive for the affected economies. However, education should be a crucial factor here, since it is the responsibility of higher education institutions to educate and train their students not only on relevant specific contents but also, on values (by complying with the Global Code of Ethics for Tourism and The 2030 Agenda, for example) and innovation.

There is still a lot of work to be done and much expertise to be shared. But in a sector with such a long tradition, we must always remember, and believe, that innovation and creativity are the keys to success. 


\section{BIBLIOGRAPHY}

Debarbieux, B., Oiry Varacca, M. Rudaz, G. Maselli, D. Kohler, T., \& Jurek, M. (eds.). (2014). Tourism in Mountain Regions: Hopes, Fears and Realities. Sustainable Mountain Development Series. Geneva, Switzerland: UNIGE, CDE, SDC.

Global Spa Summit. (2011). Wellness Tourism and Medical Tourism: Where do Spas Fit? Retrieved March 14, 2017, from http://www.globalspaandwellnesssummit. org/images/stories/pdf/spas_wellness_medical_tourism_report_final.pdf.

Global Wellness Institute. (2016). Wellness now a \$3.72 trillion global industry. Retrieved March 14, 2017, from https://www.globalwellnessinstitute.org/ wellness-now-a-372-trillion-global-industry.

ISO (International Organization for Standardization). (2017). ISO/TC 228 "Tourism and related services". Retrieved March 14, 2017 , from http://isotc.iso. org/livelink/livelink? func $=11$ \&objAction $=$ browse \&objld $=8927644$.

MedHalt. (2016). How economies are earning billions in medical tourism revenues. Retrieved June 7, 2017, from http://medhalt.com/blog/economies-earningbillions-medical-tourism-revenues.

PEMANDU (Performance Management and Delivery Unit). (2010). Economic Transformation Programme. Malaysia's Government.

Portugal Ventures. (2016). Industry 4.0. Retrieved March 7, 2017, from http:// www.portugalventures.pt/en/content/industry-40.

Stone, M.J., Migacz, S., \& Wolf, E. (2016). 2016 Food Travel Monitor. World Food Travel Association, Portland, Oregon, USA.

The American Institute of Stress. (2014). 2014 Stress Statistics. Retrieved June 8, 2017, from https://www.stress.org/daily-life.

The World Bank. (2017). Disability. Retrieved June 8, 2017, from http://www. worldbank.org/en/topic/disability.

TripAdvisor. (2017). Travel trends for the Silk Road 2017. Guide prepared for the UNWTO Silk Road Programme 2017. Retrieved March 15, 2017, from http://cf.cdn.unwto.org/sites/all/files/pdf/unwto_silk_road_2017_for_print_ pf.pdf.

UNWTO. (2001). Global Code of Ethics for Tourism. Retrieved January 7, 2017, from http://cf.cdn.unwto.org/sites/all/files/dpcpdf/gcetbrochureglobalcodeen. pdf.

UNWTO. (2016a). Exploring Health Tourism: Working Paper. elSBN: 978-92844-1721-6.

UNWTO. (2016b). Press Release 16085. 7 November.

UNWTO. (2016c). Press Release 16100. 5 December.

UNWTO. (2016d). Tourism Highlights. Retrieved October 20, 2016, from 


\section{Egitania}

s c i e $\Omega$ c i a

http://www.e-unwto.org/doi/pdf/10.18111/9789284418145.

UNWTO. (2017a). 1st UNWTO World Conference on Smart Destinations:

Outcome Document. Retrieved March 3, 2017, from http://sdt.unwto.org/ smartdestinations.

UNWTO. (2017b). A Roadmap for Celebrating Together - World Tourism Organization UNWTO. Retrieved March 23, 2017, from http://cf.cdn.unwto. org/all/files/docpdf.

UNWTO. (2017c). International Year of Sustainable Tourism for Development.

Retrieved May 31, 2017, from http://www.tourism 4development2017.org. 